\title{
Optimization of Sulfonated Chemi-Mechanical Pulping of Palm Oil Empty Fruit Bunch Using Response Surface Methodology
}

\author{
Yang Ping, Kai Liu, Peiqi Lyu, Lihuan Mo,* and Jun Li * \\ In order to optimize the sulfonated chemi-mechanical pulping of palm \\ oil empty fruit bunch, the response surface methodology was \\ employed. It was intended to determine the optimum level of sodium \\ sulfite dosage, sodium hydroxide dosage, maximum cooking \\ temperature, and cooking time at the sulfonation stage, and their \\ influences on paper sheets properties were analyzed. An optimum \\ compromise was obtained, and the sodium sulfite dosage, sodium \\ hydroxide dosage, maximum temperature, and cooking time were \\ $18 \%, 4 \%, 155{ }^{\circ} \mathrm{C}$, and $100 \mathrm{~min}$, respectively. The density, bursting \\ strength index, tensile strength index, and tearing strength index were \\ $0.5622 \mathrm{~g} / \mathrm{cm}^{3}, 2.60 \mathrm{kPa} \cdot \mathrm{m}^{2} / \mathrm{g}, 45.01 \mathrm{~N} \cdot \mathrm{m} / \mathrm{g}$, and $7.53 \mathrm{mN} \cdot \mathrm{m}^{2} / \mathrm{g}$, \\ respectively.
}

Keywords: Oil palm empty fruit bunch; SCMP; Response surface methodology

Contact Information: State Key Laboratory of Pulp and Paper Engineering, South China University of Technology, Guangzhou 510641, China;

*Corresponding authors: lihuanmo@scut.edu.cn; ppjunli@scut.edu.cn

\section{INTRODUCTION}

Wood shortages, environmental pollution, and high-energy consumption remain major obstacles hindering the development of today's pulp and paper industry (Yue et al. 2016). The pulp and paper industry is a resource-intensive industry, and the adequate availability of pulp and paper raw materials, including waste paper and non-wood, are essential to the industry. For a long time, limited wood raw materials have brought the industry difficulty and uncertainty in the supply chain (Hubbe 2014). Therefore, non-wood raw materials including bamboo, rice straw, bagasse, and reed have become important raw material resources for the pulp and paper industry because of their wide sources, abundance, and low prices (Marín et al. 2009; Sharma et al. 2011; Ferhi et al. 2014; Ooi et al. 2017; Emmclan et al. 2018). Palm oil empty fruit bunches (POEFB), the industrial residue of the palm oil production process, generally have been treated by direct incineration (Colonia et al. 2019). This treatment not only fails to fully utilize the value of the biomass itself, but it also causes serious environmental pollution. Additionally, this approach does not comply with the notion of sustainable economy, so it is necessary to find other applications to increase the value of the empty fruit bunch, such as making pulp out of the lignocellulosic-rich POEFB (Colonia et al. 2019). According to the statistics, for every ton of palm oil produced, there will be 1.1 tons of POEFB produced (Shinoj et al. 2011). Therefore, the advantages of POEFB for the pulp and paper industry include its large stock, low price, and easy accessibility as it is collected in the palm oil factory.

POEFB has been investigated as a raw material for pulp and paper production. The 
earliest research into the pulping of POEFB was reported by Muthurajah and Peh (1977), where the researchers used this kind of material for kraft cooking. In terms of chemical composition, POEFB is similar to hardwood, but the pentosan content is higher (Sannigrahi et al. 2010; Shinoj et al. 2011) and the physical properties of POEFB paper sheets are slightly poorer than the sulphate paper made from hardwood. Daud and Law (2011) pointed out that the palm fruit bunch fiber exhibited an average length of $0.99 \mathrm{~mm}$ and a width of $19.1 \mu \mathrm{m}$ in their research, which is consistent with it being a good papermaking raw material. Because of the greater stiffness and thicker walls of POEFB fibers, POEFB pulp could be bleached more easily by hydrogen peroxide than aspen pulp. Furthermore, Jiménez et al. (2009) obtained POEFB pulp by soda-anthraquinone pulping under the optimal experimental conditions ( $15 \%$ soda dosage, $170{ }^{\circ} \mathrm{C}, 70 \mathrm{~min}$, and 2400 numbers of PFI beating revolutions), and the properties of pulp were $59.6 \mathrm{Nm} / \mathrm{g}$ tensile strength index, $4.48 \%$ stretch, $4.17 \mathrm{kN} / \mathrm{g}$ bursting strength index, and $7.20 \mathrm{mNm}^{2} / \mathrm{g}$ tearing strength index.

An environmentally friendly and energy-saving pulping method is needed, especially for non-woody materials. Although palm oil empty fruit bunches have been reported in chemical pulping in recent years, the study of palm empty fruit bunches in high yield pulp has rarely been reported. Sulfonation chemi-mechanical pulping (SCMP) is a kind of high yield pulping method developed in the 1970s. It has attracted attention for its high pulp yield, low pollution, good strength, and low energy consumption (Liu 2007).

SCMP is a multivariate and heterogeneous reaction process. In a multivariable system, the influence of a single variable on the experimental results does not represent the interaction of multiple variables unless all other conditions are kept constant. Therefore, this kind of experimental method does not fully explain the influence of each factor and analyze the interaction between different factors. The response surface method (RSM) is a technique that is particularly well suited for this situation, combining a planned and efficient experimental design approach with a least squares model to determine the optimal conditions for process response (Tan et al. 2009).

In the present study, by using the hand sheets properties (density, bursting strength index, tensile strength index, and tearing strength index) as indicators, the effects of sulfonation factors (sodium sulfite dosage, sodium hydroxide dosage, maximum temperature, and cooking time) on the sulfonation results during the sulfonation pretreatment were investigated. As mentioned earlier, the complex effects of the pulping variables on each response are tested and analyzed by a central composite design (CCD) method in a statistical experimental design RSM. For ease of analysis, Design-Expert 11.1.2 software was used to optimize the aforementioned parameters.

\section{EXPERIMENTAL}

\section{Materials}

The POEFB was obtained from Heng Huat Group (Pulau pinang, Malaysia) and washed with hot water at $80{ }^{\circ} \mathrm{C}$ to remove impurities such as dust, dirt, and grease on the surface of the raw material. The washed empty fruit string was squeezed, centrifuged, airdried at room temperature, cut to a length of $10 \mathrm{~cm}$, and placed in a plastic bag to balance the moisture content. 


\section{Methods}

Measurement of fiber dimensions and chemical composition

The representative POEFB fiber raw material sample was selected and cut into a length of about $2 \mathrm{~cm}$. Then, the sample was boiled to remove the air. After the sample sunk to the bottom of the water-filled container, it was taken out and soaked in a 1:1 solution of glacial acetic acid and hydrogen peroxide $(30 \mathrm{wt} \%)$ at a temperature of $60{ }^{\circ} \mathrm{C}$. It took 30 to $48 \mathrm{~h}$ to fully disperse and bleach the fibers. The obtained fibers were washed with distilled water to neutralize the $\mathrm{pH}$ and were collected after the water was filtered.

The POEFB fiber dimensions were characterized as follows: fiber length, fiber diameter, and lumen width of 200 randomly selected fibers were measured using a light microscope (DMi8; Leica, WEertzlar, Germany). Average fiber dimensions were calculated and relevant parameters were determined based on the following equations:

Fiber wall thickness $=($ Fiber diameter - Lumen width $) / 2$

Runkel ratio $=2 \times($ Wall thickness/Lumen width $) \times 100$

Flexibility coefficient $=($ Lumen width/ Fiber diameter $) \times 100$

$$
\text { Slenderness ratio }=(\text { Fiber length/Fiber diameter })
$$

Regarding the chemical composition, the benzene alcohol extraction and ash were measured according to TAPPI T204 CM-97 (1997) and TAPPI T211 om-93 (1993), respectively. The contents of lignin and cellulose were determined according to the method of notional renewable energy laboratory (Sluiter et al. 2008). All experiments were carried out twice, and the average values were reported in this paper.

\section{Experimental design}

According to the Box-Behnken center combination design principle in the response surface analysis experiment software Design-Expert 11.1.2, the study of SCMP POEFB consisted of 6 central experiments and 24 peripheral experiments. The sodium sulfite dosage, sodium hydroxide dosage, maximum temperature, and cooking time used were $12 \%, 15 \%$, and $18 \%$ (on oven dry raw material); $2 \%, 3 \%$, and $4 \%$ (on dried raw material); and $120{ }^{\circ} \mathrm{C}, 140{ }^{\circ} \mathrm{C}$, and $160{ }^{\circ} \mathrm{C}$; and $60 \mathrm{~min}, 80 \mathrm{~min}$, and $100 \mathrm{~min}$, respectively. The operational variables were normalized according to Eq. 5,

$$
X_{i}=2 \frac{X-\bar{X}}{X_{\max }-X_{\min }}
$$

where $X_{\mathrm{i}}$ is the normalized value of sodium sulfite dosage (SS), sodium hydroxide dosage (SH), maximum temperature (MT), and cooking time (CT); $X$ is the absolute experimental value of the variable concerned; $\bar{X}$ is the mean of the extreme values of $X$; and $X_{\max }$ and $X_{\min }$ are the maximum and minimum value of $X$.

Optimization of sulfonated processing conditions for POEFB SCMP was carried out using the following methodology:

Initial design - central composite

Study type - response surface

Design model - quadratic 
Independent variables - sodium sulfite dosage, sodium hydroxide dosage, maximum temperature, and cooking time

Response - density, bursting strength index, tensile strength index, and tearing strength index

\section{Pulping}

The POEFB SCMP pulping process consists of three different stages. Firstly, the sulfonation pretreatment of POEFB was conducted in a horizontal rotary digester. At this stage, $300 \mathrm{~g}$ (o.d.) of treated POEFB were pretreated with sulfonation using a 4 Lhorizontal rotary digester (NO. 2611; Kumagai Riki Kogyo Co., Ltd., Tokyo, Japan). The process included $12 \%$ to $18 \%$ of sodium sulfite, $2 \%$ to $4 \%$ of sodium hydroxide, a maximum temperature ranging from $120{ }^{\circ} \mathrm{C}$ to $160{ }^{\circ} \mathrm{C}$, and cooking time at the maximum temperature for $60 \mathrm{~min}$ to $100 \mathrm{~min}$. The liquor-to-solid ratio was 5:1, and the digester temperature was raised to the maximum in $70 \mathrm{~min}$. Then, the pretreated POEFB was defibrated three times under an atmospheric pressure and room temperature using a continuous high-consistency disc refiner (2500-II; Kumagai Riki Kogyo Co., Ltd., Tokyo, Japan) at a high consistency ( $25 \%$ to $30 \%$ ). The clearance between two refining discs was set at $0.5 \mathrm{~mm}$ for the first and second defibrate process. The stock refined twice was screened with a $0.2 \mathrm{~mm}$ diaphragm screen, and the rejects were refined another time at a clearance of $0.2 \mathrm{~mm}$ and screened again. The accepts from the first screening and the second screening were mixed and stored as POEFB SCMP. Finally, post-refining was conducted on POEFB SCMP to further improve the properties using a PFI refiner under 5000 revolutions according to ISO 5264-2 (2002), and the SCMP refined was stored in a refrigerator for subsequent operation.

\section{Paper sheet making and hand sheet properties measurement}

The POEFB SCMP handsheets were produced in accordance with ISO 5269-2 (2004). The prepared handsheets were placed in a constant temperature and humidity (23 ${ }^{\circ} \mathrm{C}, 50 \% \mathrm{RH}$ ) laboratory for $24 \mathrm{~h}$, and the relevant properties were measured. Basic paper properties of basis weight, thickness, and brightness were measured. The physical properties, including bursting strength, tensile strength, and tearing strength, were measured in accordance with ISO 2758 (2014), ISO 1924-2 (2008), and ISO 1974 (2012), respectively. Indexes of those properties were calculated to avoid the errors brought by basis weight difference.

\section{RESULTS AND DISCUSSION}

\section{Raw Material Characterization}

The dimensions of POEFB fibers and the relevant data from the literature are shown in Table 1. The dimensions of POEFB were in accordance with those reported by Law and Jiang (2001). Although the fiber length of POEFB is generally shorter than other non-wood fibers, the composite performances of POEFB are superior. The Runkel classification value was obtained by dividing cell wall thickness by lumen diameter, and it was analyzed to prove whether this raw material is suitable for pulping and papermaking (Xu et al. 2006). It is expected that the Runkel proportion is smaller than 1. The obtained value of 0.51 indicates that the cell wall of POEFB is thin and fibers obtained from POEFB are suitable 
for the production of paper. The anticipated slenderness ratio value of fibers for papermaking is over 33 (Kiaei et al. 2011). The slenderness ratio for POEFB was 52.2, which was higher than 33 and beneficial for papermaking. The higher flexibility coefficient indicates the fiber is more flexible. According to Table 1, it can be concluded that POEFB fibers suits paper production better than bagasse and rice straw for pulping and papermaking.

Table 1. Properties of POEFB and Relevant Data from the Literature

\begin{tabular}{|c|c|c|c|c|c|c|c|c|}
\hline Material & $\begin{array}{c}\text { Length } \\
(\mathrm{mm})\end{array}$ & $\begin{array}{c}\text { Diameter } \\
(\mu \mathrm{m})\end{array}$ & $\begin{array}{c}\text { Lumen } \\
\text { width } \\
(\mu \mathrm{m})\end{array}$ & $\begin{array}{c}\text { Cell wall } \\
\text { thickness } \\
(\mu \mathrm{m})\end{array}$ & $\begin{array}{c}\text { Runkel } \\
\text { ratio }\end{array}$ & $\begin{array}{c}\text { Slend. } \\
\text { ratio }\end{array}$ & $\begin{array}{c}\text { Flex. } \\
\text { Coeff. }\end{array}$ & Ref. \\
\hline POEFB & 0.96 & 18.4 & 12.2 & 3.10 & 0.51 & 52.2 & 66.3 & This study \\
\hline $\begin{array}{c}\text { EFB } \\
\text { strand }\end{array}$ & 0.99 & 19.1 & 12.4 & 3.38 & 0.55 & 51.8 & 64.8 & $\begin{array}{c}\text { Law et al. } \\
2001\end{array}$ \\
\hline $\begin{array}{c}\text { Canola } \\
\text { straw }\end{array}$ & 1.31 & 31 & 19.5 & 5.75 & 1.25 & 42.3 & 62.9 & $\begin{array}{c}\text { Hosseinpo } \\
\text { ur et al. } \\
2010\end{array}$ \\
\hline Bagasse & 1.59 & 20.96 & 9.72 & 5.63 & 1.16 & 76.0 & 46.4 & $\begin{array}{c}\text { Khakifirooz } \\
\text { et al. } 2012\end{array}$ \\
\hline $\begin{array}{c}\text { Rice } \\
\text { straw }\end{array}$ & 0.83 & 10.89 & 4.57 & 3.16 & 1.38 & 76.6 & 42.0 & $\begin{array}{c}\text { Kiaei et al. } \\
2011\end{array}$ \\
\hline $\begin{array}{c}\text { Wheat } \\
\text { straw }\end{array}$ & 1.17 & 15.9 & 10.2 & 2.83 & 0.55 & 73.6 & 64.4 & $\begin{array}{c}\text { Moradian } \\
\text { et al. } 2001\end{array}$ \\
\hline
\end{tabular}

The chemical composition of POEFB fibers is listed in Table 2, and the results are in accordance with Liu et al. (2019). The cellulose content of POEFB is slightly lower than canola straw and bagasse, but higher than rice and wheat straw. In previous studies, it has been proven that rice straw (Lam et al. 2001; Juwono and Subawi 2014) and wheat straw (Hedjazi et al. 2009; Nasser et al. 2015) can be used for pulping and papermaking, and ideal physical properties could be obtained. This confirms the feasibility of POEFB being used as feedstock for the production of paper.

Table 2. Chemical Composition of POEFB and Other Non-Wood Raw Materials

\begin{tabular}{|c|c|c|c|c|c|}
\hline Material & $\begin{array}{c}\text { Cellulose } \\
(\%)\end{array}$ & Lignin (\%) & $\begin{array}{c}\text { Benzene } \\
\text { alcohol } \\
\text { extraction (\%) }\end{array}$ & Ash (\%) & Ref. \\
\hline POEFB & 44.5 & 22.8 & 4.1 & 1.4 & This study \\
\hline EFB strand & 42.7 & 17.2 & 0.9 & 0.7 & Khoo and Lee 1991 \\
\hline $\begin{array}{c}\text { Canola } \\
\text { straw }\end{array}$ & 48.5 & 20 & - & 6.6 & $\begin{array}{c}\text { Hosseinpour } \text { et al. } \\
2010\end{array}$ \\
\hline Bagasse & 55.57 & 20.50 & 3.25 & 1.85 & $\begin{array}{c}\text { Khakifirooz et al. } \\
2012\end{array}$ \\
\hline Rice straw & 41.20 & 21.9 & 0.56 & 9.2 & $\begin{array}{c}\text { Sannigrahi et al. } \\
2008\end{array}$ \\
\hline Wheat straw & 34.9 & 18.5 & 7.62 & 7.56 & $\begin{array}{c}\text { Tozluoğlu et al. } \\
1990\end{array}$ \\
\hline
\end{tabular}

\section{Analysis of Optimized POEFB SCMP Pulping Process by RSM}

Table 3 summaries the experimental results for the physical properties of paper sheets made of POEFB SCMP pulps with the normalized and real values of the operational 
variables. Based on the statistical analyses provided, the quadratic model was selected. Experimental data were modelled using the following second-order polynomial Eq. 6 ,

$$
\mathrm{Y}=\mathrm{A}_{0}+\sum_{i}^{k} \beta_{i} X_{i}+\sum_{i}^{k} \beta_{i i} X_{i}^{2}+\sum_{i<j}^{k} \beta_{i j} X_{i} X_{j}
$$

where $Y$ is the estimate for a response variable pulp bulk, bursting strength index, tensile strength index, and tearing strength index; $k$ is 4 , the total number of operational variables $\left(X_{\mathrm{i}}\right) ; \beta_{\mathrm{s}}$ is the estimate of a regression parameter computed by the least-squares method or named as least squares coefficients; and $X \mathrm{i}, X_{\mathrm{i}}^{2}$, and $X_{\mathrm{i}} X_{\mathrm{j}}$ are the linear effects, the quadratic effects, and the two-variable interaction effects, respectively.

Table 3. Experimental Conditions in Normalized Values According to Central Composite Design and the Results of Four Responses for POEFB SCMP

\begin{tabular}{|c|c|c|c|c|c|c|c|c|}
\hline \multirow[b]{3}{*}{ No. } & \multirow{2}{*}{\multicolumn{4}{|c|}{$\begin{array}{l}\text { Pulping variables } \\
\text { Normalized values }\end{array}$}} & \multicolumn{4}{|c|}{ Response } \\
\hline & & & & & \multirow[b]{2}{*}{$\begin{array}{l}\text { Density } \\
\left(\mathrm{g} / \mathrm{cm}^{3}\right)\end{array}$} & \multirow{2}{*}{$\begin{array}{l}\text { Bursting } \\
\text { strength } \\
\text { index } \\
\left(\mathrm{kPa} \cdot \mathrm{m}^{2} / \mathrm{g}\right)\end{array}$} & \multirow{2}{*}{$\begin{array}{l}\text { Tensile } \\
\text { strength } \\
\text { index } \\
(\mathrm{N} \cdot \mathrm{m} / \mathrm{g})\end{array}$} & \multirow{2}{*}{$\begin{array}{l}\text { Tearing } \\
\text { strength } \\
\text { index } \\
\left(\mathrm{mN} \cdot \mathrm{m}^{2} / \mathrm{g}\right)\end{array}$} \\
\hline & SS & $\mathrm{SH}$ & MT & CT & & & & \\
\hline 1 & 1 & 1 & 1 & -1 & 0.5682 & 2.29 & 45.9 & 7.88 \\
\hline 2 & -1 & 1 & 1 & -1 & 0.5685 & 2.36 & 39.3 & 8.04 \\
\hline 3 & -1 & 1 & 1 & 1 & 0.5321 & 2.48 & 42.7 & 8.08 \\
\hline 4 & 1 & -1 & -1 & 1 & 0.4462 & 1.42 & 28.4 & 6.22 \\
\hline 5 & 0 & 0 & 0 & 1 & 0.5290 & 2.29 & 44.8 & 6.79 \\
\hline 6 & 0 & 0 & -1 & 0 & 0.4629 & 1.55 & 32.2 & 6.19 \\
\hline 7 & -1 & -1 & -1 & 1 & 0.4066 & 0.87 & 18.8 & 3.86 \\
\hline 8 & 0 & -1 & 0 & 0 & 0.5096 & 1.88 & 36.3 & 6.8 \\
\hline 9 & 0 & 1 & 0 & 0 & 0.5546 & 2.37 & 43.8 & 7.08 \\
\hline 10 & 1 & 1 & -1 & -1 & 0.4793 & 1.83 & 36.9 & 5.92 \\
\hline 11 & 1 & 0 & 0 & 0 & 0.5435 & 2.30 & 41.9 & 6.75 \\
\hline 12 & 1 & -1 & -1 & -1 & 0.4170 & 0.97 & 19.3 & 3.99 \\
\hline 13 & 0 & 0 & 0 & -1 & 0.5101 & 2.06 & 40.7 & 6.76 \\
\hline 14 & 1 & 1 & 1 & 1 & 0.5723 & 2.85 & 43.2 & 8.28 \\
\hline 15 & -1 & 1 & -1 & 1 & 0.4592 & 1.46 & 30.8 & 6.01 \\
\hline 16 & -1 & 0 & 0 & 0 & 0.5154 & 2.14 & 37.9 & 6.82 \\
\hline 17 & -1 & 1 & -1 & -1 & 0.4788 & 1.66 & 30.4 & 5.78 \\
\hline 18 & 0 & 0 & 1 & 0 & 0.5632 & 2.29 & 41.1 & 6.59 \\
\hline 19 & 1 & -1 & 1 & -1 & 0.5649 & 2.43 & 41.8 & 6.49 \\
\hline 20 & -1 & -1 & 1 & 1 & 0.5549 & 2.32 & 37.6 & 6.55 \\
\hline 21 & -1 & -1 & -1 & -1 & 0.4194 & 1.18 & 20.9 & 4.9 \\
\hline 22 & 0 & 0 & 0 & 0 & 0.5063 & 2.12 & 39.6 & 6.64 \\
\hline 23 & -1 & -1 & 1 & -1 & 0.5272 & 2.37 & 41.0 & 7.04 \\
\hline 24 & 1 & -1 & 1 & 1 & 0.5886 & 2.72 & 43.9 & 7.08 \\
\hline 25 & 1 & 1 & -1 & 1 & 0.4951 & 1.87 & 39.1 & 6.38 \\
\hline 26 & 0 & 0 & 0 & 0 & 0.5192 & 2.22 & 40.6 & 6.42 \\
\hline 27 & 0 & 0 & 0 & 0 & 0.4984 & 2.09 & 38.7 & 6.35 \\
\hline 28 & 0 & 0 & 0 & 0 & 0.5146 & 2.10 & 39.2 & 6.72 \\
\hline 29 & 0 & 0 & 0 & 0 & 0.5198 & 2.15 & 41.0 & 6.81 \\
\hline 30 & 0 & 0 & 0 & 0 & 0.4935 & 2.05 & 38.2 & 6.05 \\
\hline
\end{tabular}

Note: SS is sodium sulfite; $\mathrm{SH}$ is sodium hydroxide dosage; MT is maximum temperature; and CT is cooking time. 
Table 4. Pulp Yield during Mechanical Pulping Process and the CSF and Energy Consumption during PFI Refining

\begin{tabular}{|c|c|c|c|c|c|}
\hline No & $\begin{array}{c}\text { Total } \\
\text { yield } \\
(\%)\end{array}$ & $\begin{array}{c}\text { Screened } \\
\text { yield }(\%)\end{array}$ & $\begin{array}{c}\text { Initial } \\
\text { CSF } \\
(\mathrm{mL})\end{array}$ & $\begin{array}{c}\text { Energy } \\
\text { consumption } \\
(\mathrm{kW} \cdot \mathrm{h})\end{array}$ & $\begin{array}{c}\text { Final } \\
\mathrm{CSF} \\
(\mathrm{mL})\end{array}$ \\
\hline 1 & 75.50 & 67.13 & 700 & 49 & 320 \\
\hline 2 & 78.83 & 63.43 & 655 & 48 & 325 \\
\hline 3 & 77.74 & 69.28 & 700 & 56 & 270 \\
\hline 4 & 80.03 & 52.76 & 685 & 62 & 395 \\
\hline 5 & 78.31 & 62.83 & 655 & 54 & 215 \\
\hline 6 & 78.02 & 53.99 & 665 & 60 & 335 \\
\hline 7 & 78.29 & 54.62 & 765 & 64 & 640 \\
\hline 8 & 82.88 & 58.05 & 665 & 57 & 315 \\
\hline 9 & 77.87 & 60.30 & 655 & 50 & 310 \\
\hline 10 & 79.76 & 53.65 & 635 & 46 & 360 \\
\hline 11 & 81.42 & 66.51 & 620 & 53 & 255 \\
\hline 12 & 78.68 & 50.07 & 735 & 65 & 550 \\
\hline 13 & 76.71 & 65.61 & 635 & 55 & 260 \\
\hline 14 & 73.84 & 61.48 & 705 & 45 & 385 \\
\hline 15 & 80.63 & 55.53 & 680 & 58 & 345 \\
\hline 16 & 77.28 & 57.23 & 645 & 56 & 255 \\
\hline 17 & 75.66 & 55.78 & 670 & 59 & 300 \\
\hline 18 & 72.75 & 66.56 & 720 & 49 & 395 \\
\hline 19 & 70.46 & 65.57 & 675 & 49 & 365 \\
\hline 20 & 67.25 & 61.03 & 700 & 50 & 395 \\
\hline 21 & 82.89 & 55.30 & 735 & 62 & 485 \\
\hline 22 & 90.34 & 61.01 & 670 & 58 & 270 \\
\hline 23 & 77.58 & 64.81 & 665 & 54 & 305 \\
\hline 24 & 73.62 & 65.15 & 715 & 49 & 390 \\
\hline 25 & 84.45 & 59.66 & 645 & 57 & 220 \\
\hline 26 & 89.26 & 61.15 & 670 & 58 & 270 \\
\hline 27 & 89.54 & 60.66 & 675 & 58 & 275 \\
\hline 28 & 90.71 & 60.98 & 665 & 57 & 275 \\
\hline 29 & 91.02 & 62.17 & 665 & 58 & 265 \\
\hline 30 & 90.04 & 60.39 & 675 & 58 & 275 \\
\hline & & & & & \\
\hline
\end{tabular}

To establish a perspicuous model with minimum equation coefficients and also prevent over-fitting, the insignificant coefficients, which had values nearest to 0 , were deleted from the models (Leh et al. 2008). The significant coefficients and statistical data of each response are given in Table 5. The quadratic multiple regression equation estimated by CCD was used and is shown by Eq. 7,

$$
\begin{aligned}
& Y_{n}=A+B X_{S S}+C X_{S h}+D X_{M T}+E X_{C T}+F X_{S S} X_{S H}+G X_{S S} X_{M T}+H X_{S S} X_{C T}+ \\
& I X_{S H} X_{M T}+J X_{S H} X_{M T}+K X_{M T} X_{C T}+L X_{S S}^{2}+M X_{S H}^{2}+N X_{M T}^{2}+O X_{C T}^{2}
\end{aligned}
$$

The standard deviation is expected to be as low as possible and $\mathrm{R}^{2}$ is expected to be near 1 . All models were significant at a level of less than 0.0001 with satisfactory values of $\mathrm{R}^{2}$, thus confirming the sufficiency of the fitted models. The Lack of Fit indicates the probability that the predicted values of the models do not fit the actual values, and the proximity of the models obtained by the reaction fitting to the experimental data. The Pvalues (Prob. $>|t|$ ) for the Lack of Fit of each model were higher than 0.05, which indicates 
that the Lack of Fit was not significant. Therefore, it was not necessary to adjust the regression equation. Apart from the tearing strength index, the values of $R_{\text {Adj }}^{2}$ subtracting $\mathrm{R}_{\text {Pred }}^{2}$ were less than 0.2 , further indicating that the models had high credibility. $\mathrm{A}_{\text {deq }}$ precision is the reproducibility of the experimental results, generally greater than 4 . It can be seen from Table 5 that the precision corresponding to the four response values were $20.854,25.298,18.978$, and 12.433, respectively. All of these values were greater than 4 , indicating that the experimental results were repeatable. Therefore, it is possible to predict the responses with sufficient adequacy under any given experimental requirements within the limits of the variables studied by using these models.

Table 5. Statistical Analysis of Reduced Models and Coefficient of Density, Bursting Strength Index, Tensile Strength Index, and Tearing Strength Index

\begin{tabular}{|c|c|c|c|c|c|c|c|c|}
\hline \multirow[t]{2}{*}{ Factor } & \multicolumn{2}{|c|}{ Density $\left(\mathrm{cm}^{3} / \mathrm{g}\right)$} & \multicolumn{2}{|c|}{$\begin{array}{l}\text { Bursting strength } \\
\text { index }\left(\mathrm{kPa} \cdot \mathrm{m}^{2} / \mathrm{g}\right)\end{array}$} & \multicolumn{2}{|c|}{$\begin{array}{l}\text { Tensile strength } \\
\text { index }(\mathrm{N} \cdot \mathrm{m} / \mathrm{g})\end{array}$} & \multicolumn{2}{|c|}{$\begin{array}{l}\text { Tearing strength } \\
\text { index }\left(\mathrm{mN} \cdot \mathrm{m}^{2} / \mathrm{g}\right)\end{array}$} \\
\hline & $\mathrm{CE}$ & Prob. $>|t|$ & CE & Prob. $>|t|$ & CE & Prob. $>|t|$ & $\mathrm{CE}$ & Prob. $>|t|$ \\
\hline Intercept & 0.52 & - & 2.14 & - & 40.35 & - & 6.64 & - \\
\hline$X_{S S}$ & 0.012 & 0.0011 & 0.13 & 0.0001 & 2.45 & 0.0001 & 0.21 & $<0.0001$ \\
\hline$X_{S H}$ & 0.015 & 0.0001 & 0.17 & $<0.0001$ & 3.56 & $<0.0001$ & 0.58 & 0.0783 \\
\hline$X_{M T}$ & 0.054 & $<0.0001$ & 0.52 & $<0.0001$ & 6.65 & $<0.0001$ & 0.93 & $<0.0001$ \\
\hline$X_{C T}$ & $0.004-$ & 0.2066 & 0.074 & 0.0084 & 0.80 & 0.1099 & 0.15 & 0.1899 \\
\hline$X_{S S} X_{S H}$ & - & - & -0.021 & 0.4237 & - & - & -0.17 & 0.1674 \\
\hline$X_{S S} X_{M T}$ & - & - & -0.036 & 0.1810 & -0.74 & 0.1602 & -0.23 & 0.0616 \\
\hline$X_{S S} X_{C T}$ & 0.006 & 0.1040 & 0.073 & 0.0133 & 0.52 & 0.3187 & 0.18 & 0.1452 \\
\hline$X_{S H} X_{M T}$ & -0.014 & 0.0007 & -0.14 & $<0.0001$ & -2.68 & $<0.0001$ & - & - \\
\hline$X_{S H} X_{M T}$ & -0.008 & 0.0271 & - & - & - & - & - & - \\
\hline$X_{M T} X_{C T}$ & - & - & 0.046 & 0.0937 & -0.70 & 0.1855 & -0.10 & 0.4034 \\
\hline$X_{S S}^{2}$ & - & - & 0.061 & 0.3561 & -1.26 & 0.3274 & - & - \\
\hline$X_{S H}^{2}$ & - & - & - & - & -1.08 & 0.3990 & 0.16 & 0.5786 \\
\hline$X_{M T}^{2}$ & -0.013 & 0.1116 & -0.24 & 0.0021 & -4.49 & 0.0026 & -0.39 & 0.2018 \\
\hline$X_{C T}^{2}$ & - & - & - & - & 1.59 & 0.2223 & - & - \\
\hline$R^{2}$ & \multicolumn{2}{|l|}{0.9643} & \multicolumn{2}{|l|}{0.9758} & \multicolumn{2}{|l|}{0.9607} & \multicolumn{2}{|c|}{0.8874} \\
\hline$R_{A d j}^{2}$ & \multicolumn{2}{|l|}{0.9309} & \multicolumn{2}{|l|}{0.9533} & \multicolumn{2}{|l|}{0.9240} & \multicolumn{2}{|c|}{0.7823} \\
\hline$R_{\text {Pred }}^{2}$ & \multicolumn{2}{|c|}{0.8699} & \multicolumn{2}{|l|}{0.8614} & \multicolumn{2}{|c|}{0.7693} & \multicolumn{2}{|c|}{0.4599} \\
\hline $\begin{array}{l}\text { Model } \\
\text { Prod.>F }\end{array}$ & \multicolumn{2}{|c|}{$<0.0001$} & \multicolumn{2}{|c|}{$<0.0001$} & \multicolumn{2}{|c|}{$<0.0001$} & \multicolumn{2}{|c|}{$<0.0001$} \\
\hline $\begin{array}{l}\text { Lack of Fit } \\
\text { Prod.>F }\end{array}$ & \multicolumn{2}{|l|}{0.3458} & \multicolumn{2}{|l|}{0.0637} & \multicolumn{2}{|l|}{0.0547} & \multicolumn{2}{|c|}{0.0848} \\
\hline $\begin{array}{l}\text { Adeq } \\
\text { Precisior }\end{array}$ & \multicolumn{2}{|l|}{20.854} & \multicolumn{2}{|l|}{25.298} & \multicolumn{2}{|c|}{18.978} & \multicolumn{2}{|c|}{12.443} \\
\hline $\begin{array}{l}\text { Standard } \\
\text { Deviation }\end{array}$ & \multicolumn{2}{|l|}{0.013} & \multicolumn{2}{|l|}{0.10} & \multicolumn{2}{|l|}{2.01} & \multicolumn{2}{|l|}{0.47} \\
\hline
\end{tabular}

Note: $C E$ is coefficient estimate.

\section{Process Variable Effect on Physical Properties}

The sulfonation of lignin and the dissolution of lignin sulfonate were carried out simultaneously during the sulfonation treatment. The SCMP process uses a higher concentration of sulfite solution for pretreatment, which causes lignin to undergo deeper sulfonation. As a result, the fibers softened and were easier to separate, which helped improve their quality. Therefore, the concentration of sulfite solution is important in sulfonation chemical mechanical pulping. 
Figure 1 shows the effects of SS on the physical properties of the paper sheets at $\mathrm{SH}=3 \%, \mathrm{MT}=140{ }^{\circ} \mathrm{C}$, and $\mathrm{CT}=80 \mathrm{~min}$. As shown in Fig. 1, the physical properties of the paper sheets increased slightly as SS increased. The purpose of the pretreatment is to acquire maximum sulfonated lignin. With the SS increasing, the degree of sulfonation of POEFB increases (Zhang 2011), which facilitates fiber separation during refining and increases the content of long fibers, thereby improving the physical properties of the paper. These conclusions could be also supported by the data of pulp yield in Table 4. Density has a noticeable impact on the physical properties of the paper, so it is also used as a basic parameter for comparing physical properties of paper (Liu et al. 2019). As the SS is increased, the degree of sulfonation of lignin is increased, improving the hydrophilicity, flexibility, and adaptability of the fiber. Therefore, the bonding force between the fibers is increased, and other physical properties are improved as well.
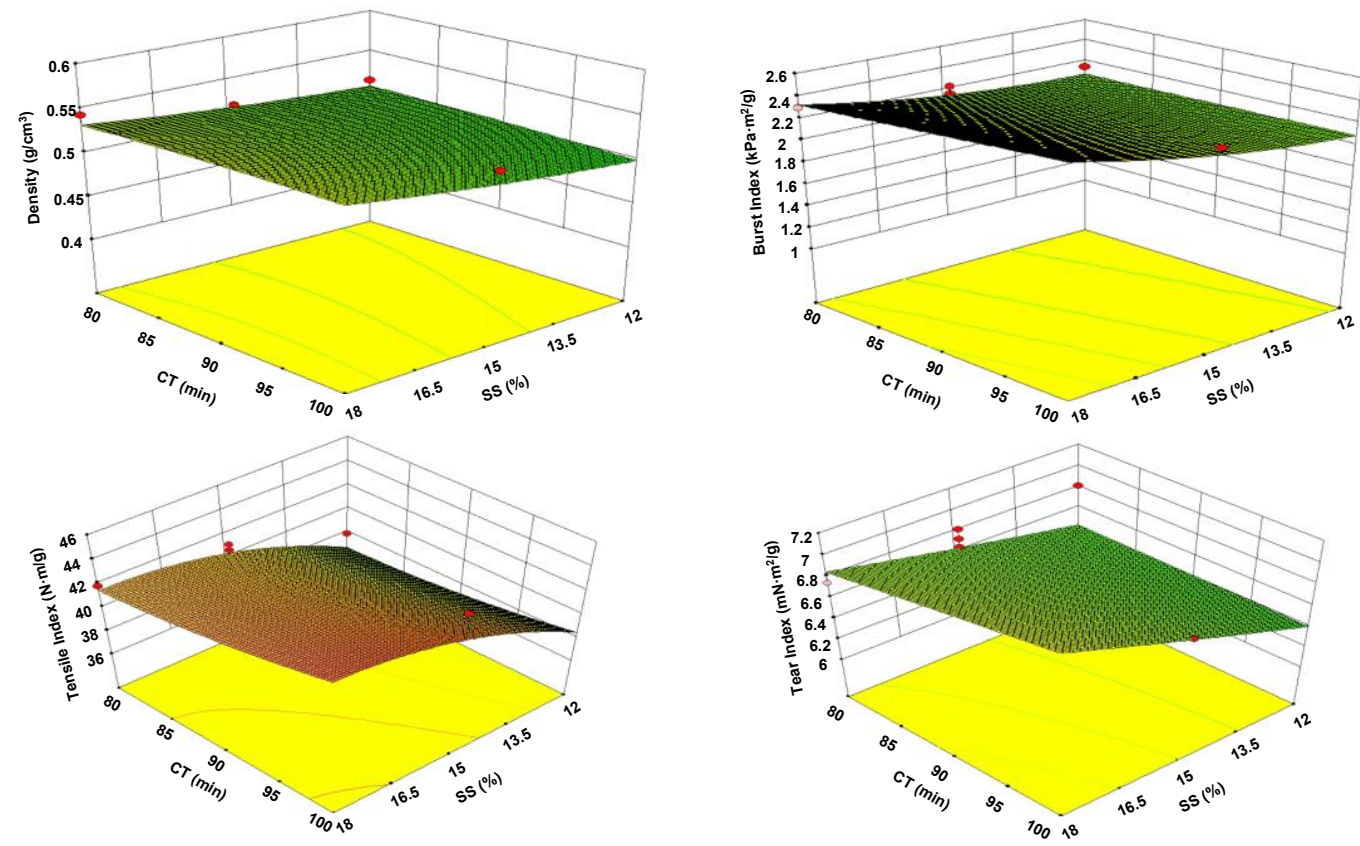

Fig. 1. 3D response surface plots of physical properties as a function of sodium sulfite dosage, at sodium hydroxide dosage $=3 \%$, maximum temperature $=140^{\circ} \mathrm{C}$, and cooking time $=80 \mathrm{~min}$

The effects of $\mathrm{SH}$ on the physical properties of the paper sheets at $\mathrm{SS}=15 \%$, MT $=140{ }^{\circ} \mathrm{C}$, and $\mathrm{CT}=80 \mathrm{~min}$ is shown in Fig. 2 . The physical properties of the paper sheets increase gradually as the SH increased. During the pretreatment, one of the main effects of sodium hydroxide is the softening of fibers. Sodium hydroxide is an ideal swelling agent and softener (Bengtsson and Simonson 1990). Sodium hydroxide make the fibers swell, then the fibers are separated and fibrillated during mechanical pulping, which enhances the flexibility of the SCMP fibers compared with mechanical pulp. When the SH is increased, the nucleophilic hydroxide ions are increased. As a result, the degradation and dissolution of lignin and carbohydrate are increased. Although excessive $\mathrm{NaOH}$ will cause a decrease in the sulfonic acid content in the slurry, the sulfonic acid group content is not the only factor determining the strength of the pulp. $\mathrm{NaOH}$ is beneficial for the penetration of chemicals, dissolution of lignin, and softening of fibers, which makes fibers separate more easily and reduces fiber cutting during refining. So, the content of long fiber was increased in the pulp, enhancing the paper sheet's strength. 

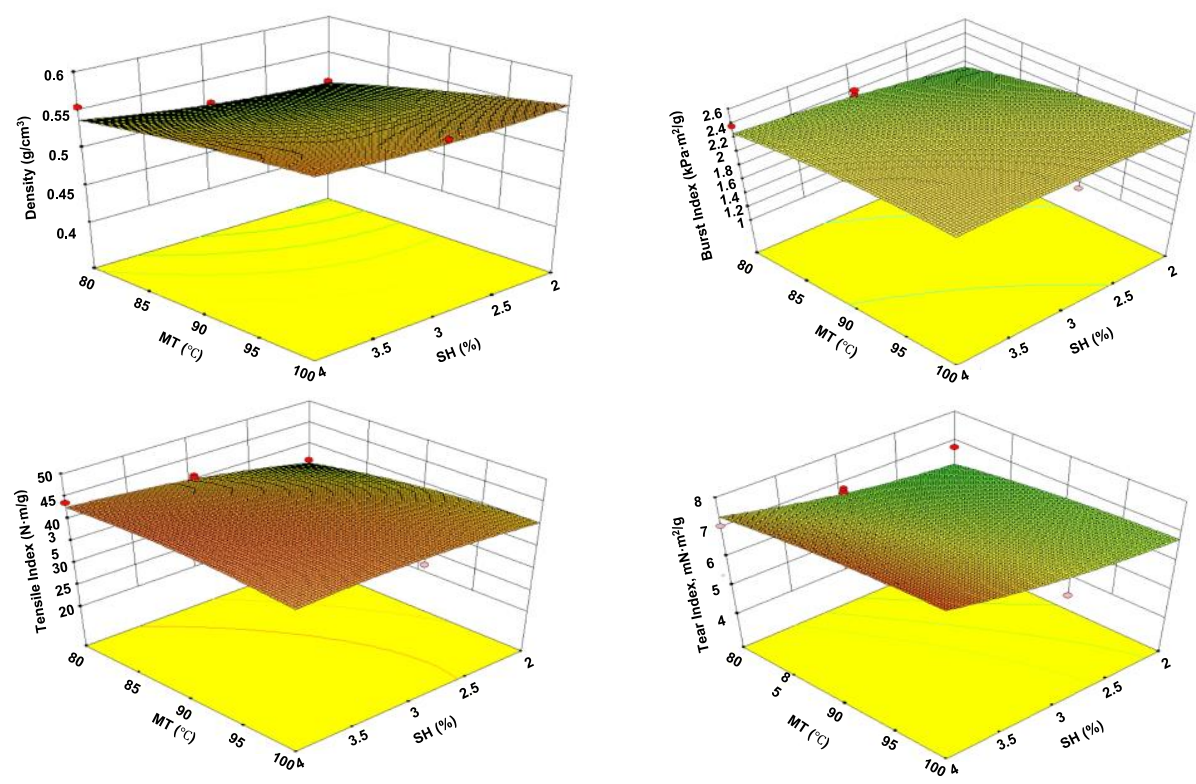

Fig. 2. 3D response surface plots of physical properties as a function of sodium hydroxide dosage, at odium sulfite dosage $=15 \%$, maximum temperature $=140^{\circ} \mathrm{C}$ and cooking time $=80 \mathrm{~min}$

Figure 3 shows the effects of MT on the physical properties of the paper sheets at $\mathrm{SS}=15 \%, \mathrm{SH}=3 \%$, and $\mathrm{CT}=80 \mathrm{~min}$. When the MT was raised from $120{ }^{\circ} \mathrm{C}$ to $160{ }^{\circ} \mathrm{C}$, the density, bursting strength index, tensile strength index, and tearing strength index of the paper sheets increased by $24.4 \%, 86.8 \%, 49.1 \%$, and $36.5 \%$, respectively. With the MT rising, it seems that the dissolution of sulfonated lignin was accelerated, and the degradation and dissolution of carbohydrates were also increased. During the sulfonation pretreatment, the sulfonation of lignin mainly takes place at lower temperatures, while the dissolution of lignin sulfonate is the major reaction at higher temperature, and an appropriate MT is necessary in balancing the sulfonation of lignin between cost (Irvine 1985). As for the paper properties, higher MT leads to higher paper density. The rise of MT is beneficial to the SCMP because it is helpful in the sulfonation of lignin and softening the fibers.
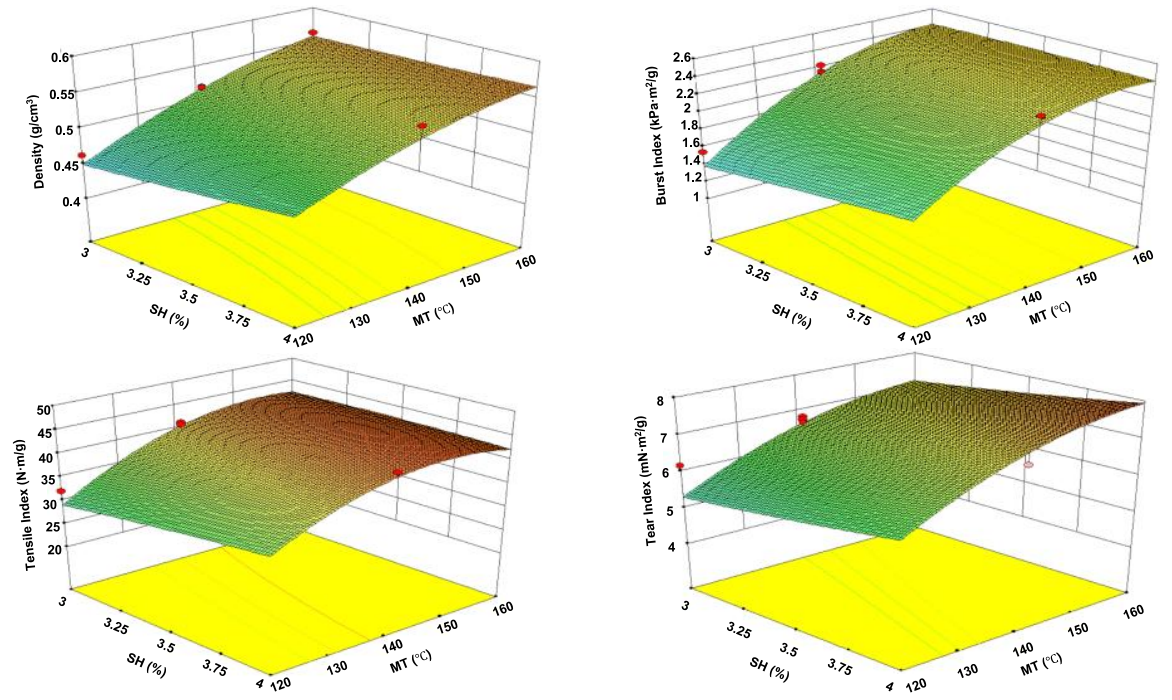

Fig. 3. 3D response surface plots of physical properties as a function of maximum temperature, at odium sulfite dosage $=15 \%$, sodium hydroxide dosage $=3 \%$ and cooking time $=80 \mathrm{~min}$ 
Figure 4 shows the effects of $\mathrm{CT}$ on the physical properties of the paper sheets at $\mathrm{SS}=15 \%, \mathrm{SH}=3 \%$, and $\mathrm{MT}=140{ }^{\circ} \mathrm{C}$. The effect of CT on the physical properties of paper sheets is small and the increase in physical properties is less than $10 \%$. Properly extending the CT would increase the sulfonation degree and long fiber content of POEFB, which could enhance the paper sheets tearing strength index and increase the paper density. Prolonging the CT is beneficial to the sulfonation reaction and fiber swelling of POEFB. With extended sulfonation reaction from longer CT, it seems that the POEFB fiber is better separated and fiber cut is reduced during refining. However, excessively prolonging the CT seems to reduce the total acid group content in the pulp, and the bonding force between the fibers seems to decrease.
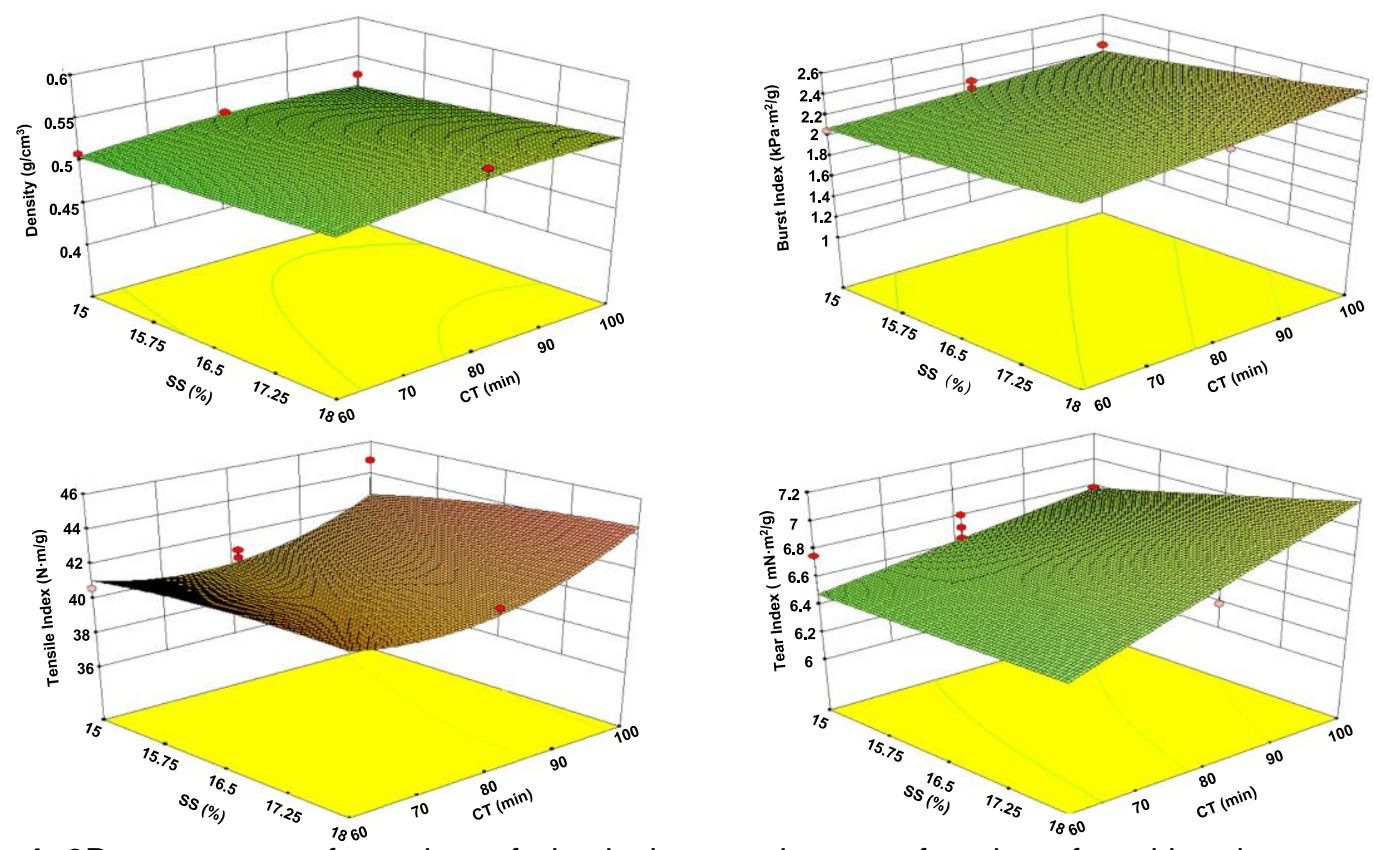

Fig. 4. 3D response surface plots of physical properties as a function of cooking time, at odium sulfite dosage $=15 \%$, sodium hydroxide dosage $=3 \%$, and maximum temperature $=140{ }^{\circ} \mathrm{C}$

Plotting the previously established polynomial equations allowed the most and least influential variables to be identified (Jiménez et al. 2009). A small P-value reflects greater influence of physical properties on the paper sheets. As shown in Table 5, the P-value of MT was the smallest, and the P-value for CT was the biggest; thus it can be concluded that the MT was more influential than the CT. This can also be confirmed from Figs. 1 through 4 according to the physical property variations. Moreover, the effect of SS on the physical properties of paper sheets was greater than that of SH. Therefore, the order (from significant to insignificant) of the effect of the operating variables on paper sheets performance was MT, SS, SH, and CT.

\section{Optimization of SCMP Pulping Condition}

Table 6 shows the maximum value of each response value under different operating variables. As can be seen from these data, there was no specific set of operating variables conditions that allow response values to reach the maximum (González et al. 2013). Therefore, to meet the particular requirement, different conditions for sulfonation are needed. That is, if the paper sheets must have a high density, the pulp should be obtained 
with low SH. However, the bursting strength index needs a medium SH and the tensile strength index requires a medium-high MT. On the other hand, the maximum tearing strength index is obtained with low SS and CT.

Table 6. Maximum Value of Each Response Value Under Different Operating Variables

\begin{tabular}{|c|c|c|c|c|c|c|}
\hline \multirow{2}{*}{ Response } & \multirow{2}{*}{ Maximum } & \multicolumn{4}{|c|}{ Normalized } & \multirow{2}{*}{ Desirability } \\
\cline { 3 - 6 } & & SS & SH & MT & CT & \\
\hline Density $\left(\mathrm{g} / \mathrm{cm}^{3}\right)$ & 0.5915 & 1 & -1 & 1 & 1 & 0.982 \\
\hline Bursting strength index $\left(\mathrm{kPa} \cdot \mathrm{m}^{2} / \mathrm{g}\right)$ & 2.78 & 1 & 0.02 & 1 & 1 & 0.990 \\
\hline Tensile strength index $(\mathrm{N} \cdot \mathrm{m} / \mathrm{g})$ & 47.31 & 1 & 1 & 0.29 & 1 & 0.994 \\
\hline Tearing strength index $\left(\mathrm{mN} \cdot \mathrm{m}^{2} / \mathrm{g}\right)$ & 8.29 & -1 & 1 & 1 & -1 & 0.998 \\
\hline
\end{tabular}

In sum, the optimal compromised operating conditions for preparing POEFB SCMP obtained by response surface analysis were $\mathrm{SS}=18 \%, \mathrm{SH}=4 \%, \mathrm{MT}=155^{\circ} \mathrm{C}$, and $\mathrm{CT}=100 \mathrm{~min}$, respectively. According to the above equation (Table 5), the physical properties of the paper can be predicted to be $0.5701 \mathrm{~g} / \mathrm{cm}^{3}$ of density, $2.75 \mathrm{kPa} \cdot \mathrm{m}^{2} / \mathrm{g}$ of bursting strength index, $46.3 \mathrm{~N} \cdot \mathrm{m} / \mathrm{g}$ of tensile strength index, and $7.97 \mathrm{mN} \cdot \mathrm{m}^{2} / \mathrm{g}$ of tearing strength index, respectively. Table 7 shows the predicted and measured values under the optimal compromised operating conditions. These values deviate 3.76\%, 1.09\%, 2.25\%, and $4.02 \%$, respectively, from their maximum values (Table 6). The measured paper physical properties obtained by experiment under these operating conditions were 0.562 $\mathrm{g} / \mathrm{cm}^{3}$ of density, $2.60 \mathrm{kPa} \cdot \mathrm{m}^{2} / \mathrm{g}$ of bursting strength index, $45.0 \mathrm{~N} \cdot \mathrm{m} / \mathrm{g}$ of tensile strength index, and $7.53 \mathrm{mN} \cdot \mathrm{m}^{2} / \mathrm{g}$ of tearing strength index, respectively. The deviation between the experimental results and the predicted values is within $10 \%$, which strongly prove that this model is reliable.

Table 7. Predicted and Measured Values Under the Optimal Compromised Operating Conditions and Deviations

\begin{tabular}{|c|c|c|c|}
\hline Response & $\begin{array}{c}\text { Predicted } \\
\text { values }\end{array}$ & $\begin{array}{c}\text { Experimental } \\
\text { results }\end{array}$ & Deviation \\
\hline Density $\left(\mathrm{g} / \mathrm{cm}^{3}\right)$ & 0.5701 & 0.5622 & $1.39 \%$ \\
\hline Bursting strength index $\left(\mathrm{kPa} \cdot \mathrm{m}^{2} / \mathrm{g}\right)$ & 2.75 & 2.60 & $5.45 \%$ \\
\hline Tensile strength index $(\mathrm{N} \cdot \mathrm{m} / \mathrm{g})$ & 46.27 & 45.01 & $2.72 \%$ \\
\hline Tearing strength index $\left(\mathrm{mN} \cdot \mathrm{m}^{2} / \mathrm{g}\right)$ & 7.97 & 7.53 & $5.52 \%$ \\
\hline
\end{tabular}

\section{CONCLUSIONS}

1. Palm oil empty fruit bunch is an ideal non-woody raw material for pulping and papermaking in terms of fiber dimensions and chemical composition.

2. The results of an experimental design applied to the SCMP pulping from POEFB were subjected to multiple regressions in order to obtain polynomial equations that reproduced the properties of the paper sheets. Additionally, the order (from significant to insignificant) of the effect of the operating variables on paper sheets performance was MT, SS, SH, then CT.

3. The optimal compromised conditions for preparing POEFB SCMP pulping by response 
surface analysis method was as follows: $\mathrm{SS}=18 \%, \mathrm{SH}=4 \%, \mathrm{MT}=155^{\circ} \mathrm{C}$, and $\mathrm{CT}=$ $100 \mathrm{~min}$. The pulp physical properties obtained by experiment under these operating conditions were $0.5622 \mathrm{~g} / \mathrm{cm}^{3}$ of density, $2.60 \mathrm{kPa} \cdot \mathrm{m}^{2} / \mathrm{g}$ of bursting strength index, $45.01 \mathrm{~N} \cdot \mathrm{m} / \mathrm{g}$ of tensile strength index, and $7.53 \mathrm{mN} \cdot \mathrm{m}^{2} / \mathrm{g}$ of tearing strength index, respectively.

\section{ACKNOWLEDGEMENTS}

The authors gratefully acknowledge the financial support of the Guangzhou Science and Technology Plan Projects (201707020011), the Special Support Plan for HighLevel Talent Cultivation of Guangdong Province (No. 2014TQ01N603), the State Key Laboratory of Pulp and Paper Engineering (201831), and the Guangdong Province Science Foundation for Cultivating National Engineering Research Center for Efficient Utilization of Plant Fibers (2017B090903003).

\section{REFERENCES CITED}

Bengtsson, G., and Simonson, R. (1990). "Chemimechanical pulping of birch wood chips," Nordic Pulp and Paper Research Journal 5(1), 16-21. DOI: 10.3183/npprj1990-05-01-p016-021

Colonia, B. S. O., Woiciechowski, A. L., Malanski, R., Letti, L. A. J., and Soccol, C. R. (2019). "Pulp improvement of oil palm empty fruit bunches associated to solid-state biopulping and biobleaching with xylanase and lignin peroxidase cocktail produced by Aspergillus sp. LPB-5," Bioresource Technology 285, 121361. DOI: 10.1016/j.biortech.2019.121361

Daud, W. R. W., and Law, K. N. (2011). "Oil palm fibers as papermaking material: Potentials and challenges," BioResources 6(1), 901-917. DOI: 10.2488/jwrs.57.42

Emmclan, L. S. H., Zakaria, M. H., and Bujang, J. S. (2018). "Utilization of aquatic weeds fibers for handmade papermaking," BioResources 13(3), 5684-5701. DOI: 10.15376/biores.13.3.5684-5701

Ferhi, F., Das, S., Moussaoui, Y., Elaloui, E., and Yanez, J. G. (2014). "Paper from Stipagrostis pungens," Industrial Crops and Products 59, 109-114. DOI: 10.1016/j.indcrop.2014.05.015

González, Z., Rodríguez, A., Vargas, F., and Jiménez, L. (2013). "Influence of the operational variables on the pulping and beating of the orange tree pruning," Industrial Crops and Products 49, 785-789. DOI: 10.1016/j.indcrop.2013.06.014

Hedjazi, S., Kordsachia, O., Patt, R., Latibari, A. J., and Tschirner, U. (2009). “Alkaline sulfite-anthraquinone (AS/AQ) pulping of wheat straw and totally chlorine free (TCF) bleaching of pulps," Industrial Crops and Products 29(1), 27-36. DOI: 10.1016/j.indcrop.2008.03.013

Hosseinpour, R., Fatehi, P., Latibari, A. J., Ni, Y., and Sepiddehdam, S. J. (2010). "Canola straw chemimechanical pulping for pulp and paper production," Bioresource Technology 101(11), 4193-4197. DOI: 10.1016/j.biortech.2010.01.055

Hubbe, M. A. (2014). "Prospects for maintaining strength of paper and paperboard products while using less forest resources: A review," BioResources 9(1), 1634-1763. DOI: 10.15376/biores.9.1.1634-1763 
Jiménez, L., Serrano, L., Rodríguez, A., and Sánchez, R. (2009). "Soda-anthraquinone pulping of palm oil empty fruit bunches and beating of the resulting pulp," Bioresource Technology 100(3), 1262-1267. DOI: 10.1016/j.biortech.2008.08.013

Irvine, G. M. (1985). "The significance of the glass transition of lignin in thermomechanical pulping," Wood Science and Technology 19(2), 139-149. DOI: $10.1007 / \mathrm{bf00353074}$

ISO 1924-2 (2008). "Paper and board - Determination of tensile properties- Part 2: Constant rate of elongation method $(20 \mathrm{~mm} / \mathrm{min})$," International Organization for Standardization, Geneva, Switzerland.

ISO 1974 (2012). "Paper - Determination of tearing resistance - Elmendorf method," International Organization for Standardization, Geneva, Switzerland.

ISO 2758 (2014). "Paper - Determination of bursting strength," International Organization for Standardization, Geneva, Switzerland.

ISO 5264-2 (2002). "Pulps - Laboratory beating- Part 2: PFI mill method," International Organization for Standardization, Geneva, Switzerland.

Juwono, A. L., and Subawi, H. (2014). "The treated rice straw as potentially feedstock of wood and rice straw fiber blend for pulp and paper making industry," in: Proceedings of the Advanced Materials Research 2014 Conference, Switzerland, pp. 318-321.

Khakifirooz, A., Ravanbakhsh, F., Samariha, A., and Kiaei, M. (2012). "Investigating the possibility of chemi-mechanical pulping of bagasse," BioResources 8(1), 21-30. DOI: 10.15376/biores.8.1.21-30

Khoo, K., and Lee, T. (1991). "Pulp and paper from the oil palm," Appita Journal 44(6), 385-388. DOI: 10.1515/hfsg.1991.45.6.469

Kiaei, M., Samariha, A., and Kasmani, J. E. (2011). "Characterization of biometry and the chemical and morphological properties of fibers from bagasse, corn, sunflower, rice and rapeseed residues in Iran," African Journal of Agricultural Research 6(16), 3762-3767. DOI: $10.5897 / A J A R 10.752$

Lam, H. Q., Le Bigot, Y., and Delmas, M. (2001). "Formic acid pulping of rice straw," Industrial Crops and Products 14(1), 65-71. DOI: 10.1016/s0926-6690(00)00089-3

Law, K. N., and Jiang, X. (2001), "Comparative papermaking properties of oil-palm empty fruit bunch," Tappi Journal 84(1), 1-13.

Leh, C. P., Rosli, W. W., Zainuddin, Z., and Tanaka, R. (2008). “Optimization of oxygen delignification in production of totally chlorine-free cellulose pulps from oil palm empty fruit bunch fibre," Industrial Crops and Products 28(3), 260-267. DOI: 10.1016/j.indcrop.2008.02.016

Liu, K., Lyu, P., Ping, Y., Hu, Z., Mo, L., and Li, J. (2019). "Chemical-free thermomechanical pulping of empty fruit bunch and sugarcane bagasse," BioResources 14(4), 8627-8639. DOI: 10.15376/biores.14.4.8627-8639

Liu, H. (2007). Effect of Non-Fibrous Components on Properties of Bamboo Pulp, Master's Thesis, Guangxi University, Nanning, China.

Marín, F., Sánchez, J., Arauzo, J., Fuertes, R., and Gonzalo, A. (2009). "Semichemical pulping of Miscanthus giganteus," Effect of pulping conditions on some pulp and paper properties," Bioresource Technology 100(17), 3933-3940. DOI: 10.1016/j.biortech.2009.03.011

Moradian, H., and Latibari, A. (2001). "Investigation on CMP pulp manufacture from wheat straw," Iranian Journal of Natural Resources 4, 469-480. DOI: 10.1016/j.biortech.2010.01.055 
Muthurajah, R., and Peh, T. (1977). "Manufacture of paper pulps from oil palm empty bunch waste," Paper Presented at the International Developments in Palm Oil; Proceedings of the Malaysian International Symposium.

Nasser, R. A., Hiziroglu, S., Abdel-Aal, M. A., Al-Mefarrej, H. A., Shetta, N. D., and Aref, I. M. (2015). "Measurement of some properties of pulp and paper made from date palm midribs and wheat straw by soda-aq pulping process," Measurement 62, 179-186. DOI: 10.1016/j.measurement.2014.10.051

Ooi, Z. X., Teoh, Y. P., Kunasundari, B., and Shuit, S. H. (2017). "Oil palm frond as a sustainable and promising biomass source in Malaysia: A review," Environmental Progress \& Sustainable Energy 36(6), 1864-1874. DOI: 10.1002/ep.12642

Rodríguez, A., Moral, A., Serrano, L., Labidi, J., and Jiménez, L. (2008). "Rice straw pulp obtained by using various methods," Bioresource Technology 99(8), 2881-2886. DOI: 10.1016/j.biortech.2007.06.003

Sannigrahi, P., Ragauskas, A. J., and Tuskan, G. A. (2010). "Poplar as a feedstock for biofuels: A review of compositional characteristics," Biofuels, Bioproducts and Biorefining 4(2), 209-226. DOI: 10.1002/bbb.206

Sharma, A. K., Dutt, D., Upadhyaya, J., and Roy, T. (2011). "Anatomical, morphological, and chemical characterization of Bambusa tulda, Dendrocalamus hamiltonii, Bambusa balcooa, Malocana baccifera, Bambusa arundinacea and Eucalyptus tereticornis," BioResources 6(4), 5062-5073. DOI: 10.15376/biores.6.4.5062-5073

Shinoj, S., Visvanathan, R., Panigrahi, S., and Kochubabu, M. (2011). "Oil palm fiber (OPF) and its composites: A review," Industrial Crops and Products 33(1), 7-22. DOI: 10.1016/j.indcrop.2010.09.009

Sluiter, A., Hames, B., Ruiz, R., Scarlata, C., Sluiter, J., Templeton, D., and Crocker, D. (2008). Determination of Structural Carbohydrates and Lignin in Biomass (NREL/TP-510-42618), National Renewable Energy Laboratory, Golden, Co.

Tan, C.-H., Ghazali, H. M., Kuntom, A., Tan, C.-P., and Ariffin, A. A. (2009). "Extraction and physicochemical properties of low free fatty acid crude palm oil," Food Chemistry 113(2), 645-650. DOI: 10.1016/j.foodchem.2008.07.052

TAPPI T204 om-97 (1997). "Solvent extractives of wood and pulp," TAPPI Press, Atlanta, GA, USA.

TAPPI T211 om-93 (1993). "Ash in wood, pulp, paper and paperboard: combustion at $525^{\circ} \mathrm{C}, "$ TAPPI Press, Atlanta, GA, USA.

Tozluoğlu, A., Özyürek, Ö., Çöpür, Y., and Özdemir, H. (2015). "Integrated production of biofilm, bioethanol, and papermaking pulp from wheat straw," BioResources 10(4), 7834-7853. DOI: 10.15376/biores.10.4.7834-7853

Xu, F., Zhong, X., Sun, R., and Lu, Q. (2006). "Anatomy, ultrastructure and lignin distribution in cell wall of Caragana korshinskii," Industrial Crops and Products 24(2), 186-193. DOI: 10.1016/j.indcrop.2006.04.002

Yue, F., Chen, K.-L., and Lu, F. (2016). "Low temperature soda-oxygen pulping of bagasse," Molecules 21(1), 85. DOI: 10.3390/molecules21010085

Zhang, H. (2011). Pulping Principle \& Engineering, Light Industry Press, Beijing, China.

Article submitted: December 3, 2019; Peer review completed: January 27, 2020;

Revisions accepted: February 10, 2020; Published: February 25, 2020.

DOI: 10.15376/biores.15.2.2630-2644 